\title{
Digital Platforms in Climate Information Service Delivery for Farming in Ghana
}

\author{
Rebecca Sarku, Divine Odame Appiah, Prosper Adiku, \\ Rahinatu Sidiki Alare, and Senyo Dotsey
}

\section{Contents}

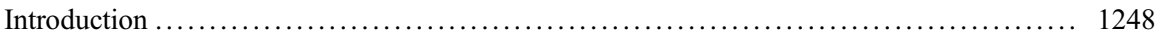

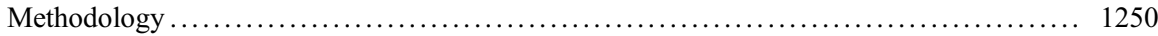

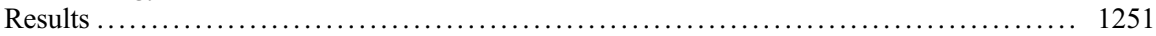

Actors Involved in the Provision of CIS with ICTs $\ldots \ldots \ldots \ldots \ldots \ldots \ldots \ldots \ldots \ldots \ldots \ldots . \ldots \ldots 1251$

Digital Platforms for the Delivery of CIS to Smallholder Farmers . . . . . . . . . . . . 1252

Category of Farmers' Use of CIS Delivered Through ICTs .................... 1263

Type of Information Needed by Different Categories of Farmers . . . . ............ 1265

Financing and Governance Arrangement for the Delivery of CIS with Digital Tools .... 1267

This chapter was previously published non-open access with exclusive rights reserved by the Publisher. It has been changed retrospectively to open access under a CC BY 4.0 license and the copyright holder is "The Author(s)". For further details, please see the license information at the end of the chapter.

R. Sarku $(\bowtie)$

University for Development Studies, Tamale, Ghana

D. O. Appiah

Environmental Management Practice Research Unit, Department of Geography and Rural

Development, Faculty of Social Sciences, Kwame Nkrumah University of Science and Technology, Kumasi, Ghana

e-mail: doappiah.cass@knust.edu.gh

P. Adiku

Institute for Environment and Sanitation Studies, College of Basic and Applied Sciences, University of Ghana, Accra, Ghana

R. S. Alare

Faculty of Earth and Environmental Sciences, Department of Environmental Sciences, C.K. Tedam University of Technology and Applied Sciences, Navrongo, Ghana

S. Dotsey

Urban Studies and Regional Science, Gran Sasso Science Institute, L'Aquila, Italy

(C) The Author(s) 2021

W. Leal Filho et al. (eds.), African Handbook of Climate Change Adaptation, https://doi.org/10.1007/978-3-030-45106-6_44 


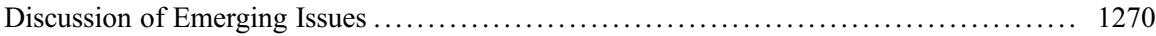

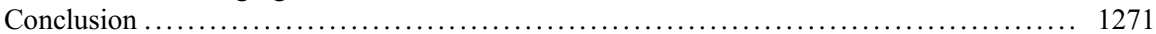

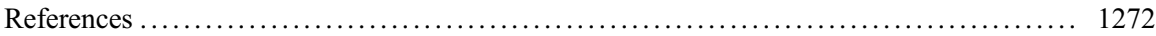

\section{Abstract}

Phone-based applications, Internet connectivity, and big data are enabling climate change adaptations. From ICT for development and agriculture perspectives, great interest exists in how digital platforms support climate information provision for smallholder farmers in Africa. The vast majority of these platforms both private and public are for delivering climate information services and for data collection. The sheer number of digital platforms in the climate information sector has created a complex information landscape for potential information users, with platforms differing in information type, technology, geographic coverage, and financing structures and infrastructure. This chapter mapped the existing climate information services and examined their impact on policy and practices in smallholder farming development in Africa, with a focus on Ghana. Specifically, the chapter provides highlights of digital platforms available to smallholder farmers and agricultural extension agents, analyzes the public and/or private governance arrangements that underpin the implementation of digital climate information delivery, and assesses the potential of these platforms in scaling up the use of climate information. The chapter contributes to understanding the dynamics of climate information delivery with digital tools in Africa, and suggests a future research agenda.

\section{Keywords}

Climate information services $\cdot$ Digital platforms $\cdot$ Smallholder farming $\cdot$ Ghana $\cdot$ Africa

\section{Introduction}

Climate change and variability are complex problems affecting different geographical regions, people, and socio-ecological systems. Africa is likely to be the most adversely affected due to its overdependence on climate-sensitive sectors for development. For instance, studies have shown that Ghana is highly prone to drought; temperatures are projected to increase at the rates of $3.8 \%\left(1.02{ }^{\circ} \mathrm{C}\right), 5.6 \%\left(1.5^{\circ} \mathrm{C}\right)$, and $6.9 \%\left(1.8^{\circ} \mathrm{C}\right)$ for the near future $(2040)$, mid-future $(2060)$, and far future (2080), respectively, and rainfall is expected to become more erratic (Dumenu and Obeng 2016). The changing climate conditions and the projections of increased temperature and precipitations have implications for smallholder farming and household food security.

The Intergovernmental Panel on Climate Change (IPCC), in recognition of the heightened climate impacts, vulnerabilities, and need for adaptation, encourages the adoption of a cross-sectoral and integrated approach to the development and 
adoption of long-term and sustainable adaptation and mitigation strategies (IPCC 2014). Adaptation, along with mitigation efforts, is a complementary approach for reducing and managing the risks associated with climate change and sustainable development particularly in developing countries (Federspiel 2013; IPCC 2014). Countries are therefore expected to develop mechanisms (plans, programs, and policies) that enhance resilience and provide support for local practices for climate change adaptation (Dougill et al. 2017).

To support farmers to better adapt to climate change and variability, contextrelevant, accurate, and timely climate information services (CIS) have become a relevant strategy (World Meteorological Organisation 2015). CIS range from climate data delivery, transformation of climate-related data together with context information into customized products such as projections, forecasts, trends, economic analyses, analysis on best practices, development and evaluation of solutions, user interactions, and capacity development (Vaughan and Dessai 2014; Vogel et al. 2019). Through the provision of CIS, farmers can make crucial decisions regarding when to plough, sow seed, apply fertilizer, and harvest, thus, reducing exposure to risks (Tall et al. 2014). It also provides actors such as agricultural extension agents, researchers, and policy-makers with the requisite knowledge to support farmers to adapt to climate change. Despite the relevance of CIS, smallholder farmers are unable to access it due to high illiteracy rates, technical information, financial constraints, sociocultural barriers, and infrastructural challenges (Singh et al. 2016, 2018). In this regard, the Global Framework for Climate Services (GFCS) has become a prominent mechanism to address these challenges (World Meteorological Organisation 2015). The framework recognizes the role of digital tools for the provision of tailored CIS to meet the needs of users including smallholder farmers (Singh et al. 2016). Digital tools include new ICTs such as smartphones and old ICTs such as radio and television (Asenso and Mekonnen 2012). The growing innovations associated with ICTs create new opportunities for information-sharing, alternative forms of connectivity, financing models, and governance arrangements (Bennett and Segerberg 2012; Karpouzoglou et al. 2016; Soma et al. 2016).

Despite the opportunities associated with the application of ICTs for the delivery of CIS in Africa, opinions abound regarding the extent to which smallholder farmers use ICT-delivered CIS.

Some of these opinions include:

- Old technologies such as radio, television, and farmers' networks remain the most relevant and cost-efficient ICT platforms for the delivery of CIS.

- ICTs remain underused despite the hype due to the lack of relevant content information, lack of or poor infrastructure, low affordability, low literacy, lack of access to ICTs, and absence of conducive social norms, such as trust.

- ICTs are social transformational tools which are enabling farmers to become coproducers of CIS rather than consumers.

- The delivery of ICT-based CIS results in changes in institutional logics in farming communities in the form of new interactions and information exchange and other forms of innovation intermediation. 
The differences in the opinions on the application of ICTs for the delivery of CIS for smallholder farmers may be attributed to the relatively underdeveloped CIS sector in Africa (Graham et al. 2015; Hansen et al. 2019). This can also be attributed to the fact that studies on CIS use among smallholder farmers in Africa are often framed under themes, such as gender, accessibility, local content development, and local knowledge, while ICTs are mostly treated as sub-themes. Based on this gap, this chapter examines the application of digital tools for the delivery of CIS for smallholder farmers with a focus on Ghana. This chapter is guided by the following questions:

- Who are the actors of ICT-based CIS delivery?

- What digital tools are used for the delivery of CIS for smallholder farming in Ghana?

- Which category of farmers applies CIS?

- What financing modes and governance arrangements are used for the delivery of CIS?

The chapter contributes to the literature on climate change adaptation in two ways: First, it provides an overview of the landscape of digital tools that are being used to provide CIS to smallholder farmers in Ghana. Second, it provides insights and directions for further research on the delivery of CIS with digital tools in Ghana in support of adaptation. The chapter consists of an "Introduction", "Methodology", "Results", and "Conclusion" sections.

\section{Methodology}

To generate data for the chapter, a systematic literature review was carried out with three databases: Scopus, Google Scholar, and CAB Abstracts. Keyword searches of terms "Climate services" AND "Ghana," "Climate information services" AND "Ghana," "Weather information" AND "Ghana," and "Weather information services" AND "Ghana" were entered as queries. "Weather and climate information services" AND "Ghana," "Climate and weather enterprise" AND "Ghana," and "Agrometeorological services AND Ghana" were conducted. Other queries include "Hydroclimatic information," "Weather information services," "Agroclimatic information," "Services," and "Information." Articles that had the abovementioned key terms in their title or abstract were selected through a process of "abstract sifting" to help align with the language, concepts, and subject matter. Since CIS is still in its infancy and now gaining attention in the literature in Africa, limited literature was generated for the period 2000 to 2020 . Hence, the snowball strategy was used to expand the scope of the literature by identifying additional literature from the selected peer-reviewed journals. Other literature which had combined themes on CIS and agricultural extension or had a regional scope on Africa with case studies on Ghana were also selected. 
Additionally, desktop search was conducted by reviewing the websites of public, nongovernmental organizations (NGOs) and business organization that provide CIS in Ghana including ESOKO; MFarm; Farmerline; e-agricultural platform; Climate Change, Agriculture and Food Security (CCAFS); African Cashew Initiative, Ignitia, Technical Centre for Agricultural and Rural Cooperation ACP-EU (CTA); US Agency for International Development (USAID); and Agricultural Cooperative Development International and Volunteers in Overseas Cooperative Assistance (ACDI/VOCA). Relevant policy documents, thesis, and gray literature were also reviewed to provide information for the analysis. The limitation of the method used for the selection of literature for the chapter is the application of only three databases. Also, new publications could have been made after the literature search was conducted. The intertwining nature of CIS, ICTs, and other broad themes could have resulted in the omission of certain literature that might have relevant information on the application of ICTs for smallholder farming in Ghana.

The content analysis of the selected literature was guided by the research question and core themes: ICTs, digital tools, CIS, smallholder farming, and Ghana. Additionally, the content of the literature was analyzed based on the geographical settings, governance arrangements, geographic scope, type of digital tools or products, content of the digital messages, stages in their development, targets in the farming sector, and organizations providing CIS with ICTs. Here, the content analysis helped categorize and structure the sub-themes in order to select new themes emerging from the literature.

\section{Results}

\section{Actors Involved in the Provision of CIS with ICTs}

The actors providing CIS with ICTs to smallholder farmers were grouped broadly since a more comprehensive analysis indicating all actors is beyond the scope and objective of this chapter.

Actors who collected weather data with ICTs include the Ghana Meteorological Agency (GMet). At the international level, international weather organizations (National Oceanic and Atmospheric Administration (NOAA) and European Organisation for the Exploitation of Meteorological Satellites (EUMETSAT)), the European Centre for Medium-Range Weather Forecasts (ECMWF), the National Aeronautics and Space Administration (NASA), UKMet, and the World Meteorological Organization also provide weather data (Mills et al. 2016; Usher et al. 2018). Farmers also constitute CIS data providers as they also generate information on local weather indicators in their communities for co-creating weather information with formal scientific models (see Kadi et al. 2011; Nyadzi 2020).

Intermediary CIS providers add value to the weather data. They include business weather data providers, like aWhere, Satelligence, and Weather Impact, mobile telecommunication network providers, and ICT platform providers (e.g., Prepeez) (Singh et al. 2018), while some knowledge institutions also play this role. Some 
actors double as intermediary CIS providers and also deliver the information directly to farmers with their ICT platforms, e.g., Farm Radio International, MFarm, Esoko, Farmerline, and VOTO Mobile among others.

The delivery of CIS information for farmers is carried out by a variety of actors from the government agencies, e.g., GMet, GTV, National Disaster Management Organization, and regional public radio channels (Adjin-Tettey 2013). International development partners in collaboration with ICT companies also provide CIS to farmers (Mohammed 2018). Businesses, commercial radio channels, and agriinput companies are also involved in the delivery of CIS to farmers. Other actors include processors, input suppliers, aggregators, exporters, agricultural service providers, and NGOs. They focus on providing complex interventions (e.g., demonstrations, visual aids, agronomic inputs, logistics, and resources) to ensure farmers' access to information (Slavova and Karanasios 2018).

\section{Digital Platforms for the Delivery of CIS to Smallholder Farmers}

This section is divided into three subsections.

\section{Data Collection and Production of CIS}

Few studies provide information on the application of ICTs for collecting data and producing CIS for the smallholder farming sector. Even so, some studies which captured data collection at the farming community level were identified. These include ground-level measurements and nowcasts that are derived from ICT-enabled platforms such as algorithms, automatic weather stations, weather models and historical observational weather data, automatic rain gauge, sensors, data logger, and ground-level radio with the aid of mobile telecommunication network radar (Gotamey et al. 2018; Usher et al. 2018; Nyadzi 2020). Global Positioning Systems (GPS) are also used to pick the location of communities, and some of the abovementioned technologies are triangulated to provide location-specific data. The mobile phone or smart technologies are also used to transmit data from weather stations in different locations to weather information producers, although carried out on a trial basis (Akudbillah 2017; Usher et al. 2018). In the case of the actual provision of weather data, the technologies are mostly based outside Ghana, and so the role of the Internet becomes relevant for data transmission (Chudaska 2018). For example, supercomputers and cell tower-mounted or co-located automatic weather stations capitalize on the increasing availability of secure, powered, connected telecommunication infrastructure in Ghana. Smartphones are used to collect personal data, type of crops cultivated, and location with Geographic Information Systems (GISs), and the data is stored to a server. Also, some organizations have researched the production of CIS with ICTs, such as chip sensors, in the northern part of the country for monitoring temperature and other weather indicators in local communities (Mills et al. 2016; Usher et al. 2018). The collection of local weather indicators with a smartphone for co-producing location-specific CIS has also been carried out on a trial basis (Nyadzi 2020; Sarku et al. forthcoming). 


\section{Data Management and Analysis}

CIS information providers usually have supercomputers, data processing, analytical models, sophisticated algorithm proprietary data sets, or multilayer ICT architecture with a system of modular components (functionalities and interfaces) that communicates with a central cloud application, which includes a central database (see Fig. 1) to interpret and convert raw data into accurate forecasts. For example, Ignitia uses supercomputers to provide real-time weather forecasts to farmers. The geospatial data collected from many locations over time are collated in a central database and then interpreted by experts (Chudaska 2018). Application Programming Interfaces (APIs) are used to deliver real-time CIS data to systems and businesses (e.g., aWhere and Farmerline). Cloud computing is used to limit the impact of unstable power and air conditioning systems in computer rooms (e.g., aWhere and Ignitia). CIS bundling is one of the key marketing strategies of market-led ICT platform information providers. It involves the collection of GPS coordinates and profiles on farmers' socioeconomic characteristics to provide value-added services such as agronomic advisory (Etwire et al. 2017; Partey et al. 2020). Some pilot projects indicate the use of different ICTs to integrate the weather data with soil and crop advice and make suggestions for minimizing losses and optimizing inputs (Eitzingera et al. 2019). Decision-support systems such as RainCast application have data source that uses OpenWeatherMap with the aid of an API to extract weather data (Omoine et al. 2013). From the API, the app retrieves temperature or weather conditions for the day and the time the condition is expected to occur for as much as 5 days ahead (Dinku et al. 2018; Gotamey et al. 2018). Mobile telecommunication networks also help to locate users in a variety of ways through network-based call detail records (CDRs), triangulation via LBS, and user registration, which enable the creation and delivery of highly localized, farm-level forecasts based on user location.

\section{Information Delivery}

To enable the delivery of CIS to farmers, the focus is mostly on the medium of information delivery due to its influence on the usability of the information for decision-making in farming (Dilling and Lemos 2011; Lemos et al. 2012). Often a distinction is made in the literature between existing and emerging technologies as "old" and "new" ICTs, respectively, based on different factors. From the social perspective, ICTs are classified as new, due to the ability to mostly complement or spur real-life interactions, and two-way communication (Materia et al. 2015; Sulaiman et al. 2012; Slavova and Karanasios 2018). They also enable alternative forms of connectivity and virtual communities for different actors (Bennett and Segerberg 2012; Cieslik et al. 2018). Another factor that is used to distinguish ICTs as either old or new is based on the capacity of the technology to collect data, process, and deliver information within a short period across space and time (Asenso-Okyere and Mekonnen 2012; Munthali et al. 2018). Also, ICTs are classified as new based on the innovations attached to the technologies such as the ability to provide mobile push-and-pull services (e.g., social media) (Bell 2015; Barber et 


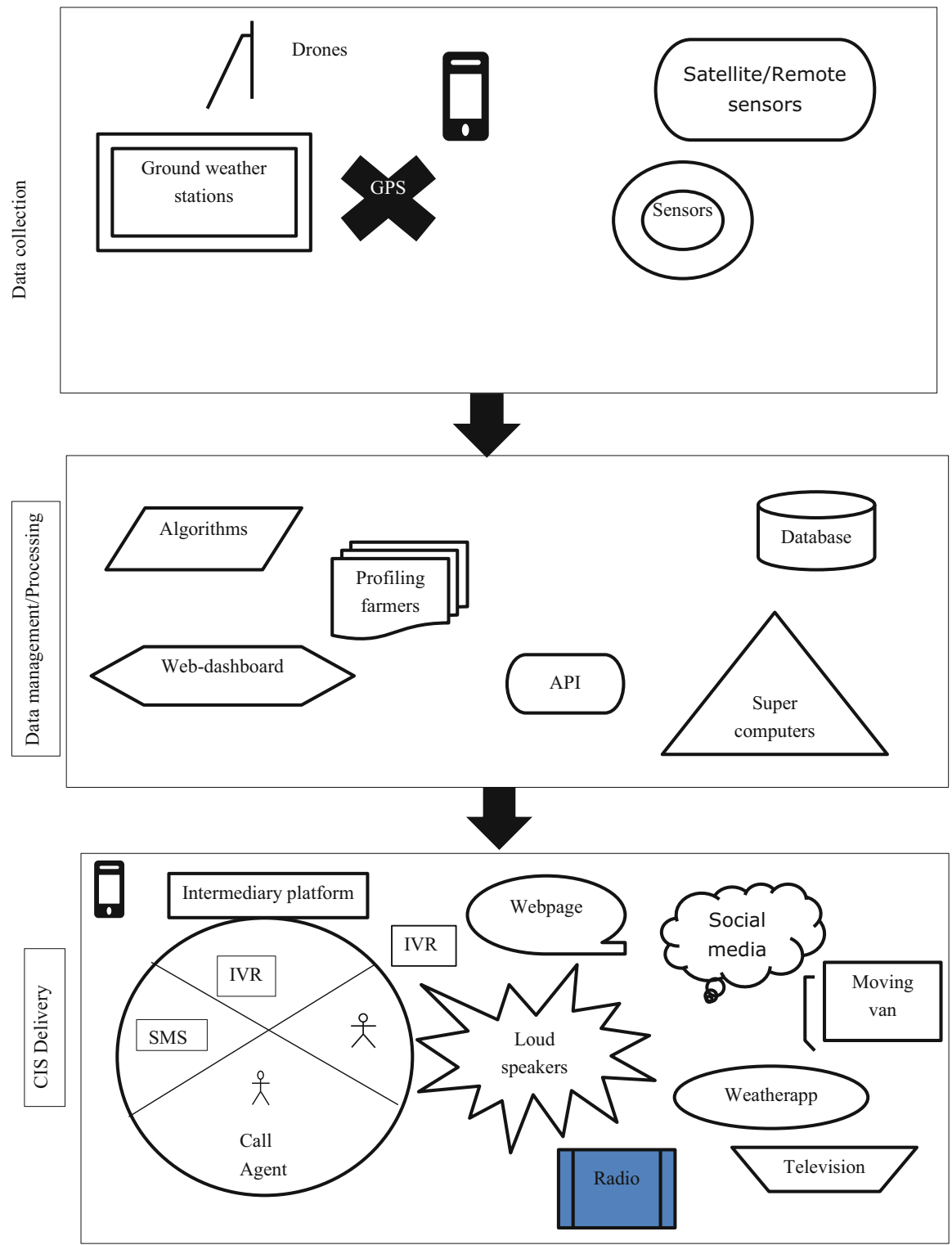

Fig. 1 Flow chart indicating how digital platforms are used for the delivery of climate information services

al. 2016; Suchiradipta and Saravanan 2016). In some instances, new technologies are identified to support environmental monitoring through the involvement of citizens in data collection (Buytaert et al. 2014; Karpouzoglou et al. 2016; Nyadzi 2020). With regard to the governance or institutional perspective, old ICTs have remained 
large under the control of state organizations, while new ICTs seem uncontrollable and have transformative powers due to the numerous actors who use it to provide information across space and time (Mol 2008; Soma et al. 2016). In reference to these factors, a plethora of new ICTs is identified for the delivery of CIS for farming (Akudugu et al. 2012; Munthali et al. 2018).

\section{New ICT}

Mobile phones for CIS delivery are increasing in Ghana due to its different functionalities. As tools for oral interpersonal communication, mobile phones have a high level of ownership among farmers (Anuga et al. 2019). Farmers stressed the importance of mobile phones as tools for accessing formal and informal networks. For instance, they are used to contact agricultural extension agents (e.g., dealing with pests) or reach out to fellow farmers for assistance (Alhassan et al. 2013). The are several advantages associated with the use of a mobile phone for the delivery of CIS (see Table 1). The functions of mobile phones used by RainCast for the delivery of CIS include a selection of options for language, location, type of forecast required, and other information related to farming (Omoine et al. 2013).

Interactive voice response (IVR) is a voice-based channel of communication; others include call centers and voicemail (Zougmoré et al. 2018). The e-extension platform for the Ministry of Food and Agriculture (MoFA) has a mobile application called Farmer Direct which allows farmers to call in and receive pre-recorded information (Modernizing Extension and Advisory Services (MEAS) 2012; Munthali et al. 2018).

The voice/audio and video messages are in the form of pre-recorded information in the local languages to meet the needs of different categories of farmers. The voice forum is a feature that allows farmers to ask questions by calling a toll-free helpline with a short code. Agricultural extension agents can answer questions via a web interface, and answers are sent to farmers as voice SMS (Slavova and Karanasios 2018).

Short message services (SMS) are short written text with description on weather conditions and other agricultural information on how to tackle pests or diseases, agricultural techniques, optimum planting times, available subsidies, and weather forecasts, local fairs, and crop prices (Aker 2011). For example, Ignitia Ghana partners with ACDI/VOCA to deliver weather forecast through SMS to farmers who are part of the Agricultural Development and Value Chain Enhancement (ADVANCE) II project. Automated SMS alerts are also used for the delivery of CIS (Mohammed 2018).

Weather apps such as AccuWeather, Rainsat, and others are installed on smartphones to provide a daily forecast. Some of these apps provide a forecast for $48 \mathrm{~h}$ or the entire week. Some weather apps are available to specific network subscribers (Caine et al. 2015). The smartphone has also enabled user-specific weather apps with an interface designed for several functionalities and applications for farmers (Gotamey et al. 2018).

Mobile-based-only platforms include MTN and Vodafone telecommunication network scribe to access CIS with SMS and IVR. Vodafone farmer clubs have 


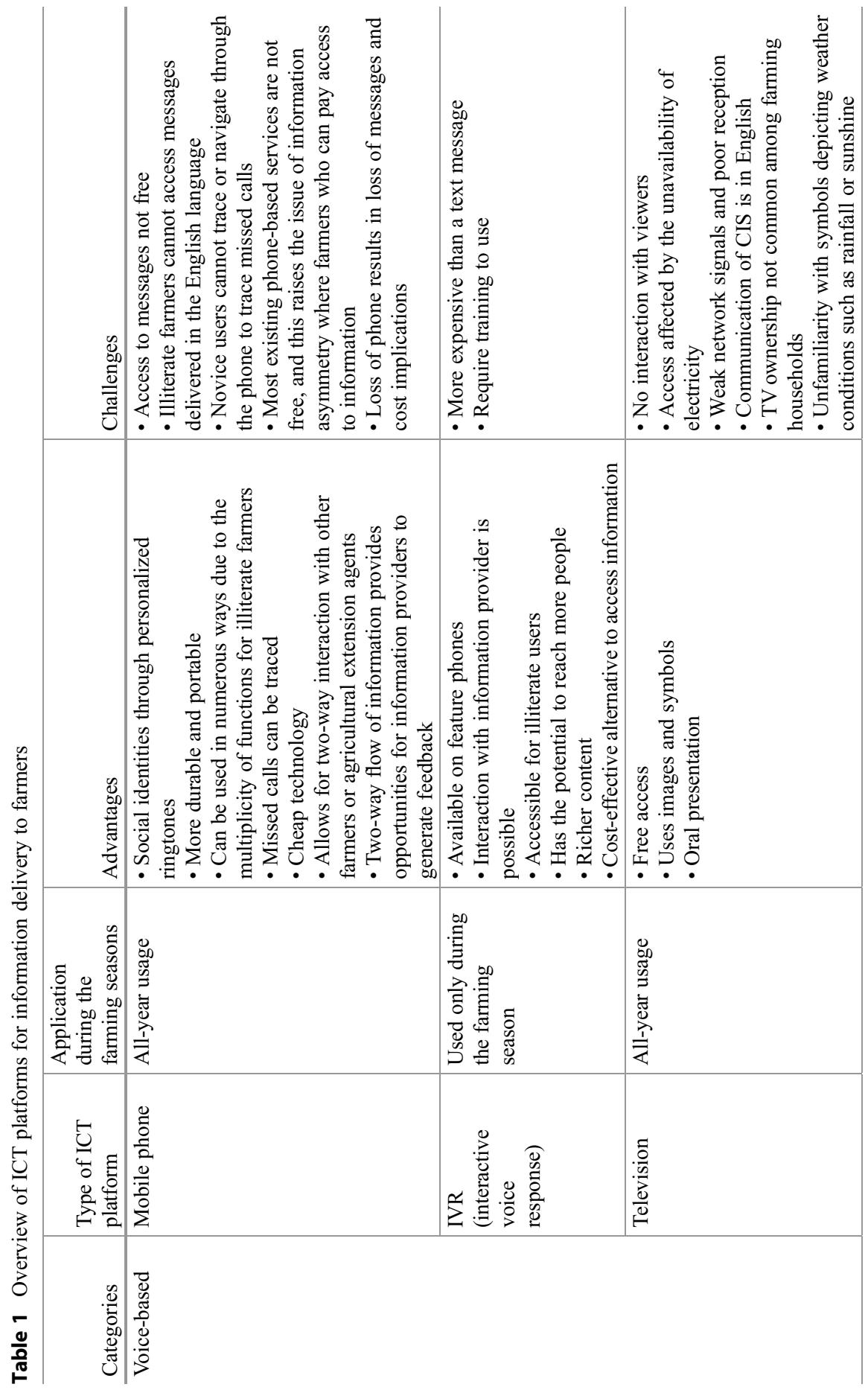




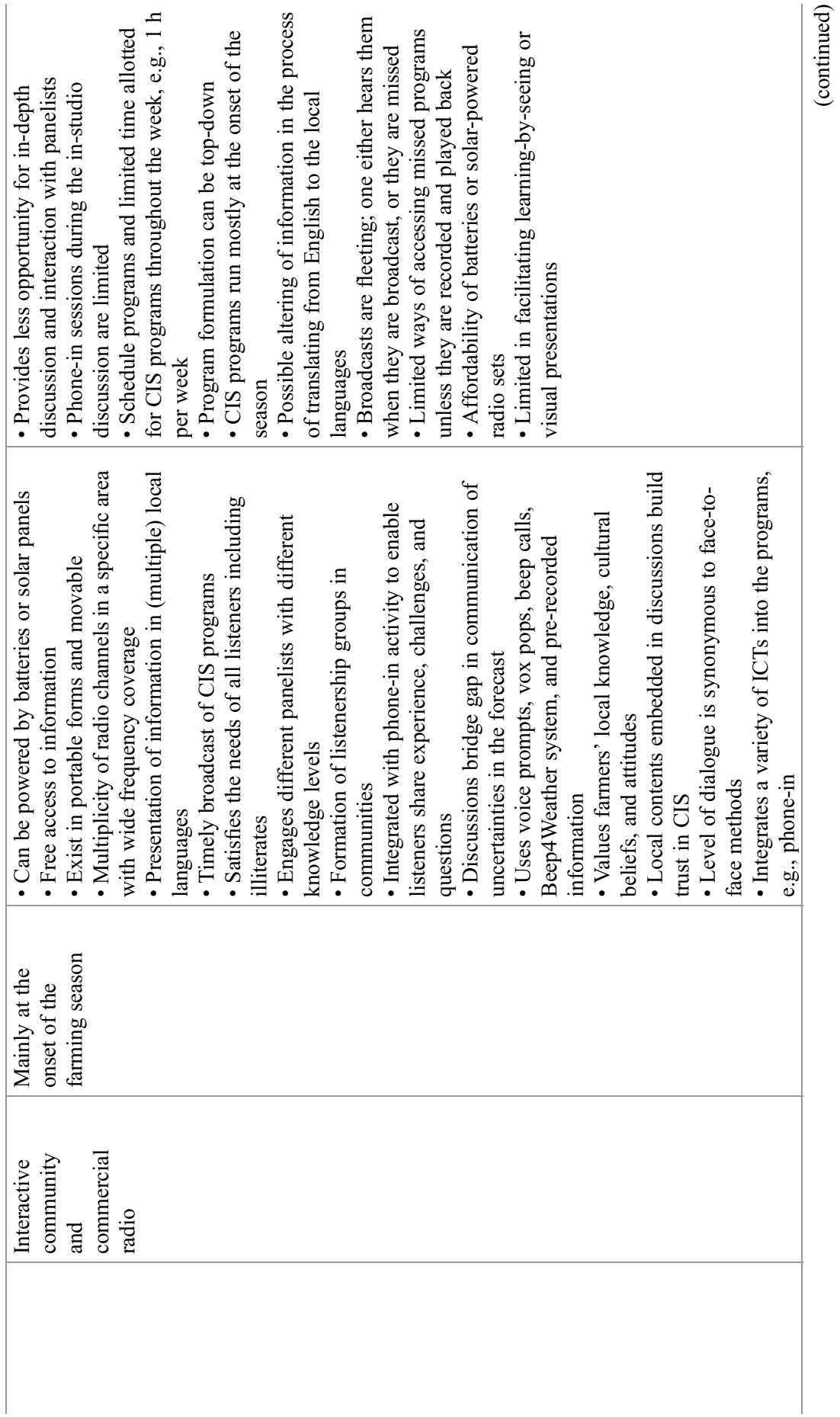




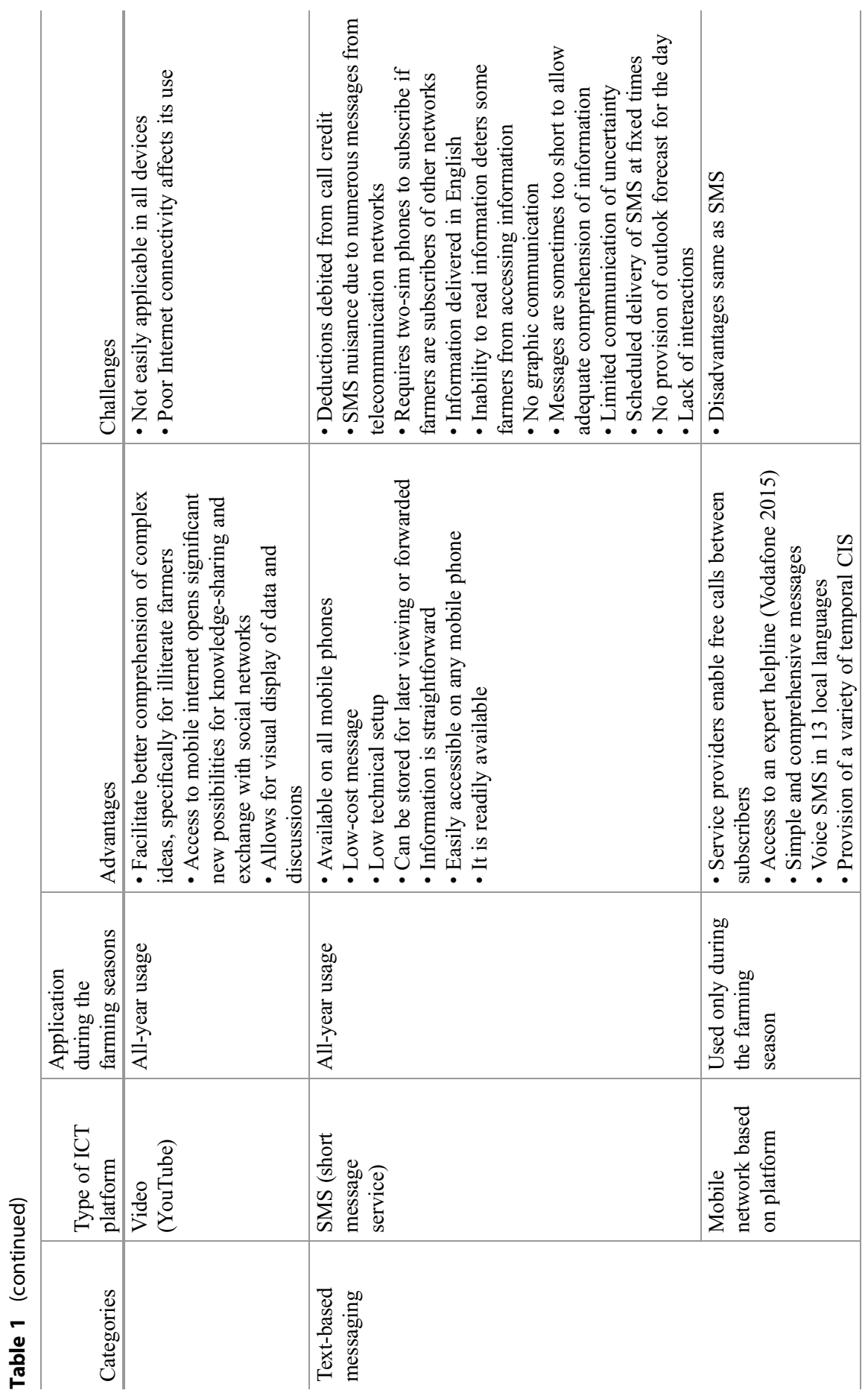




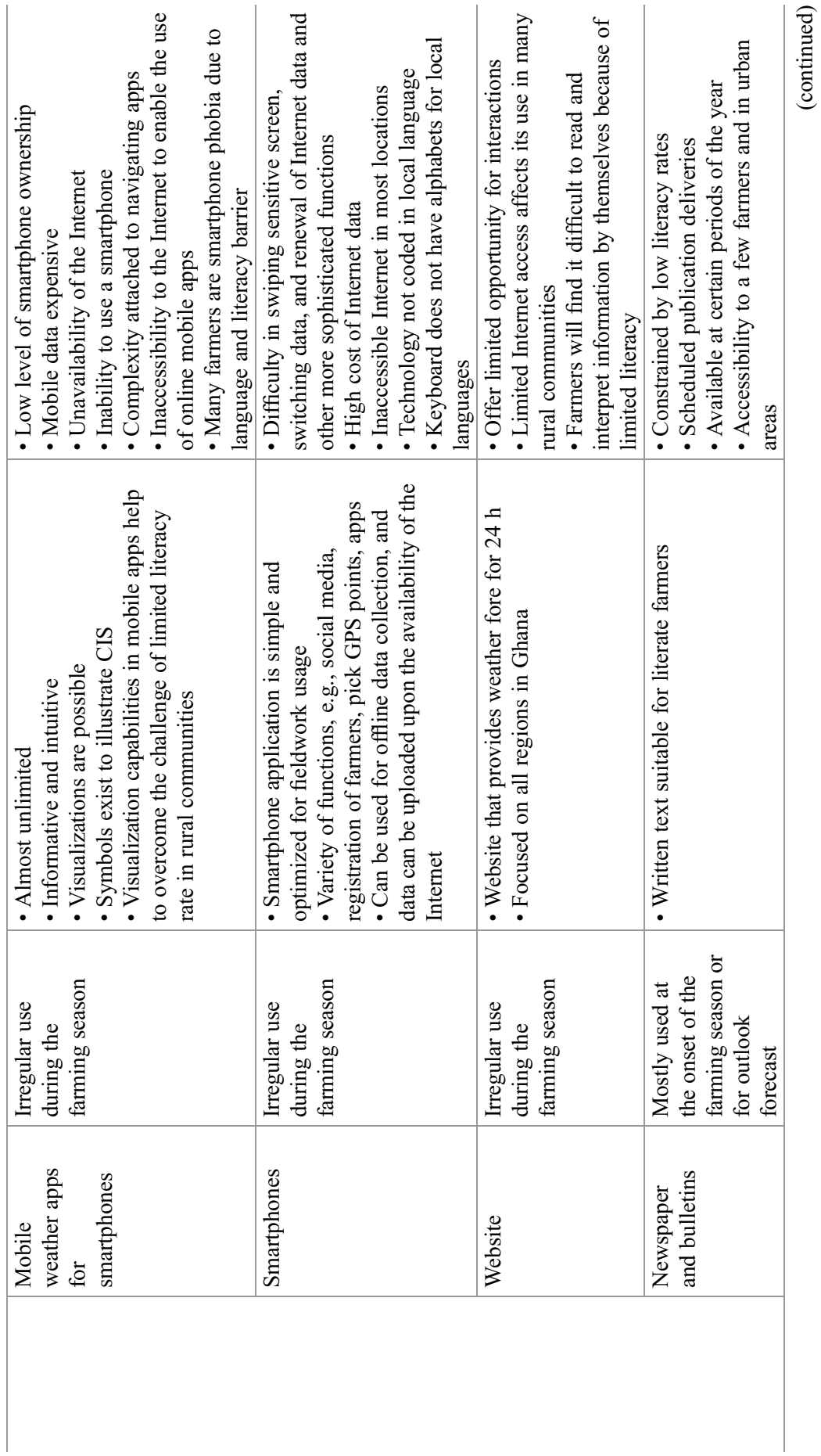




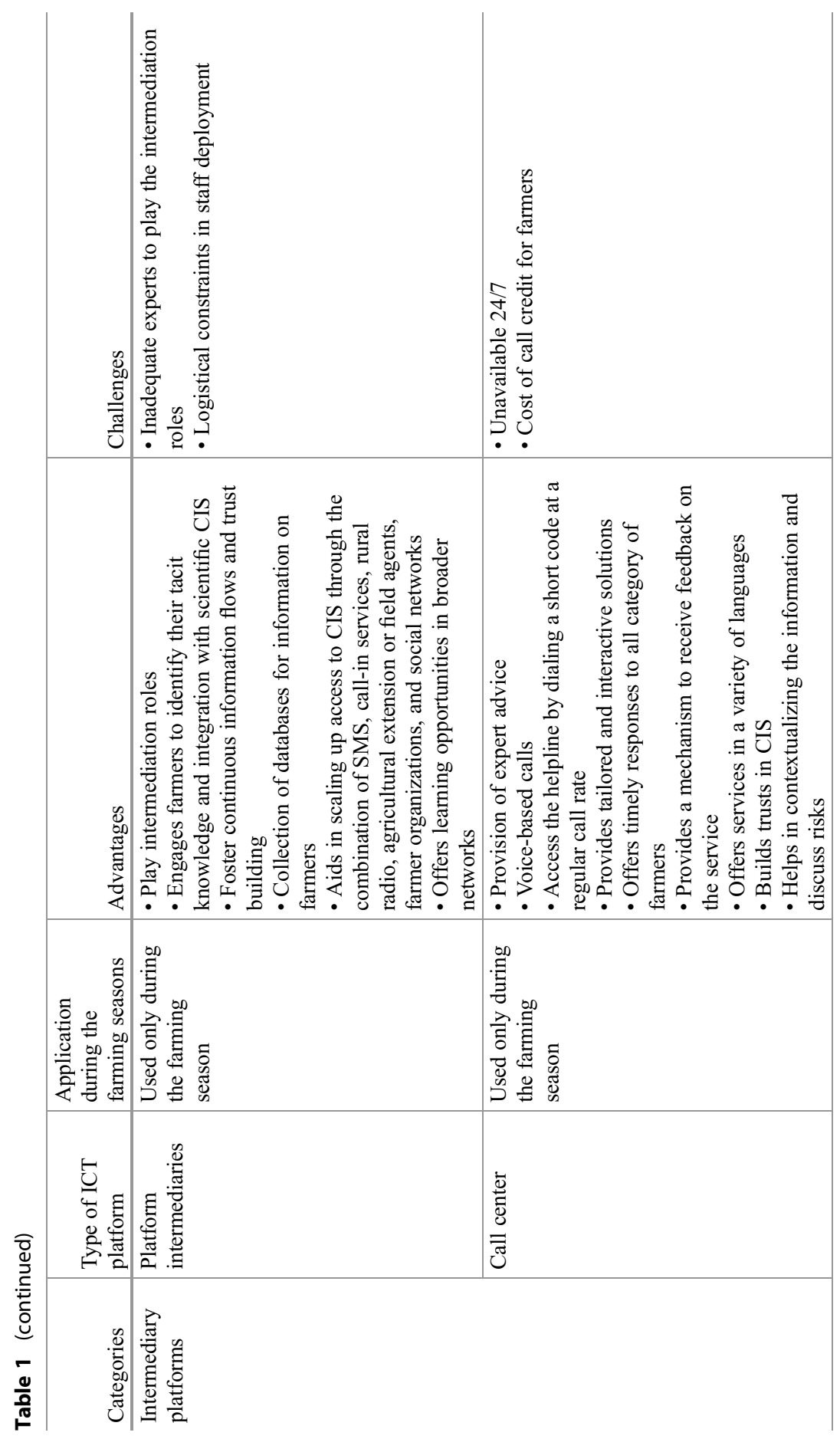




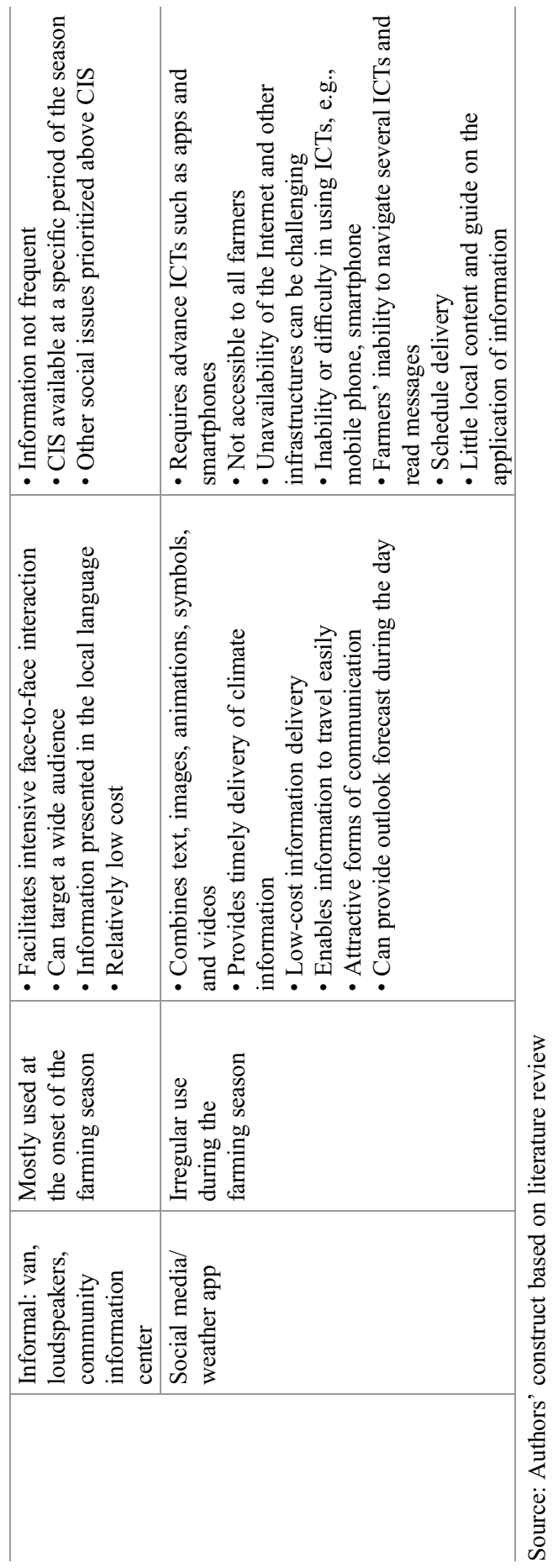


been created as part of the setup enabling the provision of information on nutrition, weather information, and market prices for eight regions in Ghana: Eastern, Western, Ashanti, Central, Northern, Volta, Brong-Ahafo, and Greater Accra (Aker et al. 2018). Vodafone has partnered with ESOKO whereby subscribers to the Vodafone network are connected to input suppliers, aggregators, extension services, and other value chain actors (Nyarko et al. 2013; Duncombe 2016).

Social media platforms such as YouTube, WhatsApp, and Facebook play a role in the delivery of CIS by GMet. YouTube video showcases a 2-minute video on nationwide weather forecasts. On GMet's Facebook page, there are flyers of impending weather conditions for the day or the bulletins to provide an outlook for changes in weather conditions on specific days. The role of WhatsApp is to provide a real-time forecast on an impending storm spotted on satellite images. At the onset of the rainy season, GMet also disseminates its seasonal forecast through YouTube or Twitter.

The website is another channel for the delivery of CIS but mostly it is not tailored for farming. Websites provide general CIS to the public on how to prepare for the dry season or impending floods (Anuga et al. 2019). For instance, during the minor season in 2019, GMet used its website to provide an overview of the weather conditions for the seasons.

Concerning print media such as the newspaper and seasonal forecast bulletins, information on the weather forecasts is communicated via state-owned electronic media and published bulletins from Ghana Media Association (GMA), Ghana News Agency, and the Daily Graphic. Some of the outlooks for the rainy season are also published in newspapers (e.g., daily graphic), and it is usually at the onset of the main season.

Intermediary platform is also used for the provision of CIS for farming. Intermediary platform consist of farmer audio library, IVR where a farmer can call a specific toll-free line and is taken through the procedures for the desired CIS in their local languages, and agricultural extension agents or field agents who are also equipped with smartphones or tablets to provide a two-way information. It also consists of a call center equipped with agents and a special telephone number (MEAS 2012, Agyekumhene et al. 2018; Munthali et al. 2018; Slavova and Karanasios 2018). With intermediary platforms, field agents or agricultural extension agents serve as mediators between the ICT platforms and farmers. These intermediaries ("infomediaries") may reside within the farming communities, access information on behalf of farmers, and discuss it with them. In some of the case studies, intermediaries are lead farmers and community knowledge brokers. Examples of intermediary platforms include ESOKO, e-agricultural platform, Smartex, and GeoFarmer (Munthali et al. 2018; Quaye et al. 2017).

\section{Old ICTs}

Despite being conventional, old ICTs are also applied in innovative ways to suit the needs of rural farming communities, especially where the use of old ICTs dominates and is intertwined with the social networks and institutional logic of farmers. This contributes significantly to enhancing the spread of information in the farming 
communities (Duncombe 2016). The chapter captured the nuanced interplay of innovation with old ICTs.

Radio is one of the conventional digital means of communication that is still relevant in the delivery of CIS to farmers in Ghana (Sam and Dzandu 2016; Nyantakyi-Frimpong 2019b). The use of radio is popular in CIS delivery for several reasons (see Table 1). Community radios, such as Simli Radio at Dalung and Radio Ada at Big Ada, create interactive programs which feature community discussions, interviews, live panel discussions, and call-in shows in local languages. CIS is broadcasted on community radios at specific days in the week when farmers are available, and special signature tunes to draw the attention of listeners (AsensoOkyere and Mekonnen 2012; Chapman et al. 2003; Nyamekye 2020). Programs are designed and periodically updated throughout the year in response to the types of CIS and agricultural information that are needed (Perkins et al. 2015). Sometimes, farmers are consulted directly during radio programs for relevant data on local indicators for the onset of the season, and comparisons are made with a scientific forecast in a panel discussion to further interpret information (Sam and Dzandu 2016). At a point in the programs, listeners are permitted to call in to interact with panelists, ask questions, and share problems and experiences. At times drama and pre-recorded programs are aired when a panel discussion is not carried out. Commercial radios also provide CIS (Chudaska 2018; Slavova and Karanasios 2018; Nyamekye 2020).

Government- and private-based television channels are other means through which farmers receive CIS, for example, GTV and TV3 (Adjin-Tettey 2013; Anuga et al. 2019). A study also indicated that some farmers also obtain weather forecasts from international television stations such as Aljazeera, $\mathrm{CNN}$, and $\mathrm{BBC}$ (Chudaska 2018).

Informal CIS delivery channels have been shown to be preferred by farmers due to oral communication and personal conversation that are mostly practiced in farming communities (Drafor and Atta-Agyepong 2005; Drafor 2016). Farmers still prefer CIS to be delivered by agricultural extension agents, workshops, village knowledge centers, and mobile vans and pamphlets produced by NGOs (NyantakyiFrimpong 2019b). Traditional information mediums like drums, loudspeakers, public address systems, gong-gong beaters, town criers, churches, and the loudspeakers of mosques are still relevant (Padgham et al. 2013; Drafor 2016). Others include CIS delivery through Ghana Information Services Department's mobile vans (Anuga and Gordon 2016; Slavova and Karanasios 2018). The information received by farmers is then communicated to others in the farming community. In some communities, CIS is displayed on notice boards, while farmer-to-farmer or farmer cooperatives are also used to facilitate information delivery (Anuga et al. 2019).

\section{Category of Farmers' Use of CIS Delivered Through ICTs}

CIS is delivered to farmers with different socioeconomic backgrounds: gender, marital status, and level of education. Mostly, men are able to access CIS with a 
variety of ICTs than women due to their ability to easily access mobile phones which are the most common new ICTs in rural communities in Ghana (Partey et al. 2019). Women's access to digital tools is limited to radio and mobile phones which are often owned by their husbands. In some cases, women who had no formal education rely on local knowledge (Chaudhury et al. 2012; Partey et al. 2019). Despite women's use of the radio as the main ICT channel to receive CIS, they are unable to access regular information due to their engagement in numerous household activities. Apart from the ownership of the ICTs, men have a higher capacity to use and operate ICTs especially the mobile phone than women without relying on others for assistance (McOmber et al. 2013). This is attributed to the level of education between men and women (Nyantakyi-Frimpong 2019b). The usage of mobile phones is limited to simple handsets with the exception of a few educated and young farmers. Young people (20-29 years) use new ICTs such as smartphones, apps, and social media. Hence, they are able to access CIS with all forms of ICTs. Within the category of men, young male farmers mostly received SMS and IVR (Partey et al. 2020).

Mostly, the beneficiaries of the CIS-funded projects select a household member or recognized owner of household land to access the information with the assumption that they would share the information with other members of their household (Mohammed 2018). With the application of such criteria, women do not access the information directly (Anaglo et al. 2014; Nyantakyi-Frimpong 2019a). Most women are unable to access CIS with ICTs because of the domination of patriarchal norms which promotes access and control of productive resources as well as decisionmaking authority by men (Nyantakyi-Frimpong 2019a). Even if women are selected to receive CIS with digital tools, the application of the criteria "one member per household" results in the selection of an adult woman. This implies that within polygamous households where seniority is a norm, it is the elderly women who gain access to CIS.

The frequency of receipt of CIS delivered through ICTs range from daily, $48 \mathrm{~h}$, 5 days, weekly, and monthly forecast. However, there are instances when lots of pending or unopened messages are seen on farmers' phones, and they wait until their literate relatives are around (Mohammed 2018). The reason for this is attributed to low levels of literacy or inability to manipulate the phone (Alemna and Sam 2006). The reliance on relatives who own ICTs to access CIS remains a challenge since their absence could mean the inability to receive information.

Farmers have different types of information needs during each stage of the farming season, and ICTs are used to meet these needs. Seasonal forecasts are CIS provided to farmers at the onset of the farming season with interactive platforms, such as radio and call center. They come with advice on how much rain to expect, the length of the season, and the onset dates (Gbetibouo et al. 2017; NyantakyiFrimpong 2019a). Additionally, SMS, IVR, bulletins, social media, websites, and print media are also used to provide seasonal forecasts to support farmers' decisionmaking on the selection of a variety of (specific) crops.

During the farming seasons, the provisions of local content- and location-specific forecast with the IVR and SMS are mostly used. Also, the weather influences crop pest and disease conditions during the farming seasons; therefore, intermediary 
platforms such as call centers are used by farmers to generate information on the application of agrochemicals (Munthali et al. 2018). Some CIS have a short-term lifespan in terms of relevance to decision-making and therefore must be delivered within an appropriate timescale to farmers (daily up to 7 days) with different forms of ICTs (Zougmoré et al. 2018). In this regard, the intensity of the rains and the number of rainy days require the provision of daily forecasts with SMS, IVR, and radio to enable decision-making on when to weed and conduct other fieldwork (Partey et al. 2020). When floods or dry spell conditions are expected to occur, radio, SMS, social media, and intermediary platforms are used as the main channels to deliver outlook for the day or week (Stigter et al. 2013). Besides, ICTs help to contextualize CIS and integrate it into farmers' own schemes of experiences (Leeuwis 2004). Some of these CIS include information on the availability of transport and tractor services, credit options, input and market prices, and crop insurance during the farming season (Adiku et al. 2017; Anuga et al. 2019). For instance, the Vodaphone farmer club SMS provides a holistic CIS such as weather information, market prices, costs and availability of inputs (seed and fertilizer), and pest recommendations (Usher et al. 2018; ESOKO 2020). At the end of the farming season, SMS, IVR, and other informal channels are prominent means of delivering CIS such as a 10-day forecast for optimum harvesting period and processing of farm produce.

\section{Type of Information Needed by Different Categories of Farmers}

Farmers' information needs are associated with major decision-making for the farming season. The decision-making includes the type of crop and the variety of seed to select, land size and the number of farmland to cultivate, when to plough, when to sow seeds, when to transplant seedlings, when to do irrigation, when to apply fertilizer and(or) agrochemicals, and when to start harvesting, marketing, and processing (Sarku et al. 2020).

The scant literature on CIS indicates that gender plays a role in the information needs of different categories of farmers. Men have more CIS informational needs to mitigate climate risk compared to women. This is due to differences in preferences and vulnerabilities to climate-related risks, access to farm resources, land ownership, access to labor, access to information, and financial resources (McOmber et al. 2013). Jost et al. (2016) also indicated that limited access to finance, extension services, and farm resources affected women CIS needs. Furthermore, access to a mobile phone, access to irrigation, type of crop produce, and land ownership were influential in determining whether or not someone will use CIS (Partey et al. 2020). Table 2 shows an overview of the information needs for categories of farmers.

The first key decision for the farming season in relation to the application of CIS is the type of crop and the related variables that need to be cultivated. In most households, this decision is the responsibility of household heads who are mostly men. In some contexts, the household head and spouse (or spouses if polygamous) discuss privately and communicate with the rest of the family (Nyamekye 2020). 
Table 2 Information needs of categories of farmers

\begin{tabular}{|c|c|c|c|c|c|}
\hline \multirow[b]{2}{*}{$\begin{array}{l}\text { Type of } \\
\text { forecasts }\end{array}$} & \multirow[b]{2}{*}{ Information needs } & \multicolumn{4}{|c|}{ Categories of farmers } \\
\hline & & $\begin{array}{l}\text { Young } \\
\text { men }\end{array}$ & $\begin{array}{l}\text { Young } \\
\text { women }\end{array}$ & $\begin{array}{l}\text { Elderly } \\
\text { men }\end{array}$ & $\begin{array}{l}\text { Elderly } \\
\text { women }\end{array}$ \\
\hline \multirow[t]{3}{*}{$\begin{array}{l}\text { Seasonal } \\
\text { forecast }\end{array}$} & $\begin{array}{l}\text { Type of crop and the variety of } \\
\text { seed to select }\end{array}$ & & & $\checkmark$ & $\checkmark$ \\
\hline & $\begin{array}{l}\text { Land size and number of } \\
\text { farmland to cultivate }\end{array}$ & & & $\checkmark$ & $\checkmark$ \\
\hline & When to plough & $\checkmark$ & $\checkmark$ & & \\
\hline \multirow[t]{5}{*}{$\begin{array}{l}\text { Daily-weekly } \\
\text { forecast }\end{array}$} & $\begin{array}{l}\text { Sowing of seeds or } \\
\text { transplanting of seedlings }\end{array}$ & $\checkmark$ & & $\checkmark$ & \\
\hline & $\begin{array}{l}\text { When to apply fertilizer and } \\
\text { other agrochemicals }\end{array}$ & $\checkmark$ & & $\checkmark$ & \\
\hline & When to weed & $\checkmark$ & $\checkmark$ & $\checkmark$ & $\checkmark$ \\
\hline & When to start harvesting & $\checkmark$ & $\checkmark$ & $\checkmark$ & $\checkmark$ \\
\hline & Marketing and processing & & & & $\checkmark$ \\
\hline Legend & $\checkmark$ & \multicolumn{4}{|c|}{ Applicable to specific category of farmers } \\
\hline
\end{tabular}

Source: Authors' construct based on literature review

This implies that young men's and women's information need concerning CIS is mostly dependent on the household heads (Nyantakyi-Frimpong 2019b).

Once farmers decide on the type and variety of crop(s) to cultivate, the next information needs is a forecast on the onset of the rainfall. This information is required to decide on when to prepare the land. Since land is usually prepared when soil moisture is assumed to be high, arrangement for land preparation with a tractor or manual labor becomes the responsibility of the male in the farming household (Chudaska 2018; Partey et al. 2020).

Sowing of seeds or transplanting of seedlings is carried by all categories of farmers after a rainfall. With this practice, CIS is needed by all categories of farmers. Additionally, men usually carry out the application of agrochemicals (e.g., application of fertilizer, weedicides, pesticides, and insecticides). Considering the cost of farm inputs and the availability of labor, CIS is needed by all categories of farmers to decide on when to apply agrochemicals (Sarku et al. 2020). The provision of a forecast on the amount or frequency of rainfall for the farming season is also required by all categories of farmers since it enables them to make arrangements for labor to augment household effort (Nyamekye 2020).

The study deduced that women's information needs to follow the same pattern as men yet it is tied to their relationship with men due to the unavailability of resources at their disposal. In instances where women are in charge of a household and need to take decisions concerning when to start farming, they often consult the men in the household or experienced male farmers in the communities (Nyantakyi-Frimpong 2019a, b). In some cases, women more often than not expect their husbands to provide them with information or determine the various aspect of the decisions for the farming season even when they operate different farms due to their husband's control over the household (Etwire et al. 2017; Partey et al. 2020). This finding adds 
evidence to support the growing call for the provision of CIS with ICTs which suit the needs of different categories of farmers.

\section{Financing and Governance Arrangement for the Delivery of CIS with Digital Tools}

CIS is a public good that can be accessible to all farmers to enable them to adapt to changing weather and climatic conditions. Yet the application of digital tools for the delivery of CIS has several costs associated with data collections, weather models, Internet data, and telecommunication networks. Therefore, CIS delivery in Ghana comes in the form of quasi-public good with some excludability as users pay for CIS to enable the recovery of cost (Naab et al. 2019). The cost of CIS delivery with ICTs brings to the fore discussions on farmers' willingness to pay for CIS delivered through ICTs (Quaye et al. 2017).

In this regard, two patterns can be identified: First, the majority of smallholder farmers recognize that the provision of CIS is a public good with the responsibility of the government to provide such services. Farmers who rely on free CIS delivered through the radio or television do not have access to tailored information, or they rely on their local knowledge in predicting the weather for farming (Nyantakyi-Frimpong 2013; Naab et al. 2019). Second, some farmers are willing to pay for CIS delivered through ICTs but within a minimum range (Acquah and Onumah 2011; Nantui et al. 2014). These categories of farmers have some socioeconomic characteristics such as age, sex, farm size, on-farm income, membership of a farmer-based organization, literacy level, productivity of crops in a particular season, and perception of climate change experience. Ownership and ability to use ICTs also influence farmers' decision to pay for seasonal CIS. Some studies have, however, indicated that male household heads are more willing to pay for CIS delivered through ICTs. Hence, farmers' willingness to pay for CIS delivered through ICTs is mixed and inconsistent (Adjabui 2018; Ibrahim et al. 2019). The financing mechanisms for the delivery of CIS by an organization involve several options as indicated in Table 3.

Linked to the financing model is the governance model which backs the provision of CIS with ICTs to farmers in Ghana. Although the governance model is not codified due to the absence of a CIS policy in Ghana (Naab et al. 2019), different governance modes are used for CIS delivery to farmers.

\section{Donor or NGO Governance Approach}

International donor agencies or organizations establish agricultural projects within specific agroecological zones for farmers. Some projects may be specific toward the provision of CIS, while others have different objectives (Asuru 2017). Numerous donor agencies or NGOs are operating with this governance model, and the provision of an exhaustive list is beyond the scope of this chapter. Few notable ones include ACDI/VOCA, TechnoServe, World Vision, FAO (Food and Agricultural Organization), USAID, Deutsche Gesellschaft für Internationale Zusammenarbeit (GIZ), International Fund for Agricultural Development (IFAD), CARE 
Table 3 Financing of CIS with ICTs to farmers in Ghana

\begin{tabular}{l|l}
\hline Category of CIS financiers & Funding mechanism \\
\hline Government financing & $\begin{array}{l}\text { Free provision by GMet and GTV through tax and } \\
\text { sometimes product levies }\end{array}$ \\
\hline $\begin{array}{l}\text { Financing by agri-input companies, } \\
\text { e.g., Wienco Ghana Limited }\end{array}$ & $\begin{array}{l}\text { Provides embedded services by including the cost of CIS } \\
\text { as part of the cost of the product }\end{array}$ \\
\hline Commercial output buyers & $\begin{array}{l}\text { Makes CIS freely available but incorporates the cost as } \\
\text { part of the contract farming }\end{array}$ \\
\hline $\begin{array}{l}\text { Farmer-based associations, e.g., } \\
\text { Cocoalink }\end{array}$ & $\begin{array}{l}\text { Membership fees, donor subsidies, government } \\
\text { subsidies, and contracts }\end{array}$ \\
\hline $\begin{array}{l}\text { Direct payment } \\
\text { Funded projects }\end{array}$ & $\begin{array}{l}\text { Direct fees paid through farmers' call credit or airtime, e. } \\
\text { g., Esoko }\end{array}$ \\
\hline $\begin{array}{l}\text { Contract sale } \\
\text { Bonor contracts information providers to deliver CIS } \\
\text { freely to target groups of farmers }\end{array}$ \\
\hline $\begin{array}{l}\text { Mininess advertisement on CIS } \\
\text { private partnership }\end{array}$ & $\begin{array}{l}\text { Farmers' subscription is paid by insurance companies or } \\
\text { agribusinesses }\end{array}$ \\
\hline $\begin{array}{l}\text { Sourger } \\
\text { Advertisement of agricultural products linked to the } \\
\text { provision of CIS }\end{array}$ \\
$\begin{array}{l}\text { Subsidized payment is made by farmers under a project } \\
\text { compared to those who are not part of any project }\end{array}$ \\
\hline
\end{tabular}

Source: Based on authors' literature review

International, OXFAM, and the Department for International Development (DfID) (McNamara et al. 2014). These NGOs partner mostly with market-led ICT platform information providers such as ESOKO, MFarm, Ignitia, Farmerline, and others to provide CIS to farmers. Examples include ADVANCE II, Smartex, African Cashew Initiative, and Farm Radio International's African Farm Radio Research Initiative. These projects mainly focused on specific areas such as the Guinea and Sudan savanna agroecological zone of Ghana due to the presence of donor activities in these areas (Naab et al. 2019).

\section{Public-Private Partnership}

The use of digital tools for the provision of CIS results in an interconnected network of activities between smallholder farmers and actors providing and mediating the process leading to the formation of public-private partnerships (PPP). The PPP governance mode of providing CIS for farmers involves NGOs, public sectors, mobile network telecommunication providers, market-led ICT platform information providers, and climate/weather model or satellite providers together with farming communities (Partey et al. 2019). With these arrangements, each actor provides certain resources for CIS delivery. Examples of PPP in the provision of CIS with ICTs include the CGIAR Research Programme on Climate Change, Agriculture and Food Security (CCAFS); businesses such as ESOKO, Vodafone, and Toto agric and aWhere; and public organizations that collaborate with GMet, the Council for Scientific and Industrial Research (CSIR), and MoFA to provide CIS to some 
farmers in the Upper West region under the Planting for Food and Jobs programs (Etwire et al. 2017; Partey et al. 2019, 2020).

\section{Participatory or Co-production Approaches}

ICTs enable cross production of knowledge from different sectors of society (Karpouzoglou et al. 2016; Vogel et al. 2019). In Ghana, ICTs are enabling this process through co-production of CIS with farmers' local knowledge and that of scientists. In some cases, farmers collect data on their local weather indicators, or they contribute their knowledge in several ways (Nyadzi 2020; Sarku et al., forthcoming). For example, Participatory Integrated Climate Services for Agriculture (PICSA) is an approach that has involved over 5000 farmers in Northern Ghana by using both historical climate information and forecasts to support farmers' decision-making with participatory decision-making tools that suit their contexts (Etwire et al. 2017; Clarksona et al. 2019).

\section{Farmer Organization Provision}

Another governance approach is the provision of CIS by producer cooperatives/ associations. These organizations deliver CIS to farmers in the group. Payment for the CIS is drawn from the coffers of the association or through donor support. Examples of such governance models are used by Kuapa Kokoo cooperatives, the Africa Cashew Initiative, and Cocoalink (MEAS 2012).

\section{Business Model}

Business companies use a wide variety of business models to deliver CIS, and no single model is dominant. Six different business models were identified:

- Business-to-business-to farmer model, e.g., Esoko.

- Business-to-business-to-consumer model is used between market-led ICT platform information providers (Ignitia), mobile telecommunication networks (MTN Ghana), and farmers (Chudaska 2018). Another example is farmers on the ADVANCE II project who are connected to MTN Ghana which runs the promotion sale of simple mobile phones to enable farmers to receive CIS (Mohammed 2018).

- Direct services to farmers, e.g., Vodafone farmer club where farmers pay US\$ 0.20 per month as a direct debit from their call credits to receive CIS. Subscribers also receive free airtime to call members of the group (Partey et al. 2019, 2020).

- Business to nucleus farmer and outgrower schemes is an approach that is becoming common where CIS is provided as an embedded service model. In this approach, agri-input companies, in particular, provide information about farm inputs, and CIS is added as a package. The cost of the CIS is embedded as an unidentified component of the sales price. An example of this governance approach is used by the USAID-funded ADVANCE project to promote the use of input supplies, improved seeds, and CIS (MEAS 2012; Mohammed 2018). Wienco Ghana also provides CIS with this model in the areas of cash and food 
crops for both small- and large-scale farmers in the agricultural value chain (Naab et al. 2019).

Informal governance approach for the provision of CIS includes traditional institutional arrangement used by farming communities. These are in the form of rules or norms that the farming community adheres to (Slavova and Karanasios 2018).

\section{Discussion of Emerging Issues}

First, informal channels of information delivery still hold prominence among smallholder farmers as a means for interaction. For instance, the provision of CIS by agricultural extension agents, workshops, participatory approaches, and the use of social networks are still prominent (Nyantakyi-Frimpong 2019a). Furthermore, information sources in farming communities are often embodied in knowledgeable people and shared through interactions occurring at the market, religious meetings, bus stops, community centers, and other places of meetings. Most often, the CIS is received by one person in the community, and it is shared with other members of the farming community (Kirbyshire and Wilkinson 2018). This has implications on credibility, trust, and sustainability of financial models of actors who provide CIS through ICTs. Due to the need for interactions among smallholder farmers, preferences for ICTs for the delivery of CIS still hinge on interactive technologies which provide an opportunity for farmers to ask questions and share their experiences. This suggests the need to support innovations on the use of interactive ICTs for the delivery of CIS.

Despite the limited use of new ICTs among farmers, mobile phones, in particular, have helped farmers to communicate CIS to other farmers, thereby enhancing interactions and reinforcing interpersonal relationships and norms of openness among farmers. First, mobile phones strengthened bonds in the rural community by enabling information exchanges between family, farmers, and intermediaries. Second, mobile phones complement informal ways of communicating among farmers. Therefore, norms of openness, inclusiveness, and information-sharing are strengthened rather than challenged. The findings suggest that the informal and formal channels of CIS delivery support smallholder farming institutional logic than ICTs destroying informal institutions.

Additionally, intermediaries who provide CIS with ICTs are able to exploit complementarities among digital tools and informal channels of communication. They are able to fuse characteristics and logics of informal communication channels with ICTs such as call center, IVR, and radios which relate to established patterns of interaction among smallholder farmers. The use of mobile phones, SMS alert, or peep call during radio programs is also an example. The combination of informal and ICTs helps to increase farmers' access to CIS.

Despite the evolution of sophisticated ICTs, the provision of CIS with ICTs is limited to simple ones like mobile phones, radio, and television. Thus, farmers rarely 
use social media, weather apps, and websites to receive useful CIS. Some farmers are unable to operate the phone without the assistance of relatives. This leaves the potentials of ICTs untapped for the delivery of CIS, or it results in the use of platform intermediaries. These challenges are attributed to increased sophistication of ICTs without being tailored for local farmers with literate and visual challenges and limited training on the use of ICTs (Alemna and Sam 2006; Sarku et al. forthcoming). The unavailability of local content ICTs also affects its usage as technologies are originally coded in English. In addition, many languages in Ghana use characters that are not found on the keyboards of most ICTs. Furthermore, the provision of CIS for the target group requires specific local content which affects the scalability of CIS to other agroecological locations in Ghana. There are issues regarding the affordability of ICTs such as smartphones, expensive call charges, and data (Partey et al. 2020; Etwire et al. 2017). All these challenges have implications on information asymmetry as some farmers can use ICT and access tailored CIS, while others still rely on their local knowledge for forecasting.

Findings in this chapter show that the delivery of CIS with ICT platforms are mostly piloted or funded by donors. At the end of the project, farmers are expected to subscribe to continue to receive information at a fee. However, their willingness to pay for the information raises questions about the continuity of CIS delivery. Many of the projects are designed with a top-down approach, without collaborations from farmers at the implementation stage. This raises questions on upscaling from pilot projects to larger farming communities. A limitation of relying on donors to fund the delivery of CIS with ICTs is that specific agroecological zones are targeted for a short period (McNamara et al. 2014). This affects the number of farmers who are reached within the specified period. Since climate change and variability impacts are experienced differently in specific agroecological zones in Ghana, it will be important to have nationwide CIS tailored for all farmers.

\section{Conclusion}

This chapter examined the delivery of CIS with digital tools to smallholder farmers by reviewing existing literature on the sector. Overall, our rapid scoping assessment found very positive results on the use of various digital tools for the collection, processing, and delivery of CIS to farmers. The delivery of CIS with ICTs was used mostly by men and during the farming season; a variety of ICTs are used to deliver CIS due to the level of demand for information. Old technologies, like radio, remain the most relevant and cost-efficient ICT platforms for the delivery of CIS. Some ICTs remain underused by farmers calling for the role of ICT platform intermediaries like agricultural extension agents and field agents. The delivery of CIS with ICTs results in changes in institutional logics in farming communities in the form of new interactions, information exchange, and other forms of innovation intermediation. Overall, informal information delivery channels coexist with ICT modes and are sometimes blended in various ways to provide CIS. The analysis in this chapter provides a coherent overview on the application of digital tools for the delivery of 
CIS for smallholder farming in Ghana. The emerging issues identified in the literature have contributed to the identification of areas for future research. These include (1) exploration of appropriate financial models for the sustainability and scalability of CIS delivery with ICTs; (2) application of ICTs for the delivery of CIS for other value chain actors such as processors, transporters, and aggregators; (3) increase research on how ICTs are used for data collection and production at the community level; and (4) assessment of the quality of CIS provided to smallholders.

\section{References}

Acquah HG, Onumah EE (2011) Farmers perception and adaptation to climate change: an estimation of willingness to pay. Agris On-line Papers Econ Inform 3(4):31-39

Adiku SG, Debrah-Afanyede E, Greatrex H, Zougmore RB, MacCarthy DS (2017) Weather-index based crop insurance as a social adaptation to climate change and variability in the Upper West Region of Ghana. Working paper no 189. CGIAR Research Program on Climate Change, Agriculture and Food Security, Copenhagen

Adjabui JA (2018) Farmers' willingness to participate and pay for, and agricultural extension officers' disposition to communicate weather index-based insurance scheme in Ghana: the case of the upper east region. Master thesis, Massey University

Adjin-Tettey TD (2013) The perception and usage of weather forecast information by residents of African concrete products (ACP) estates and farmers in selected communities around Pokuase in the Ga west municipality of Ghana. Int J ICT Manage I(3), 139-149.

Agyekumhene C, de Vries JR, van Paassen A, Macnaghten P, Schut M, Bregt A (2018) Digital platforms for smallholder credit access: the mediation of trust for cooperation in maize value chain financing. Wagening Journal of Life Sciences, 86-87, 77-88. https://doi.org/10.1016/j. njas.2018.06.001

Aker JC (2011) Dial "A" for agriculture: a review of information and communication technologies for agricultural extension in developing countries. Agric Econ 42:631-647

Aker PG, Gilligan J, Hidrobo DM, Ledlie N (2018) Paying for digital information: assessing farmers' willingness to pay for a digital agriculture and nutrition service in Ghana Other area references. In: 30th International conference of agricultural economist

Akudbillah NA (2017) Modelling the socio-economic benefits of the adoption of climate information: an innovative approach to subsistence farmer adaptation to climate change in GaruTempane District, Ghana. Master's thesis, University of Bergen

Akudugu MA, Guo E, Dadzie SK (2012) Adoption of modern agricultural production technologies by farm households in Ghana: what factors influence their decisions. J Biol Agric Healthc 2(3). Retrieved from https://www.iiste.org/Journals/index.php/JBAH/article/view/1522

Alemna AA, Sam J (2006) Critical issues in information and communication technologies in Ghana. Inform Dev 22(4). https://doi.org/10.1177/0266666906074181

Alhassan RM, Egyir IS, Abakah J (2013) Farm household level impacts of information communication technology (ICT)-based agricultural market information in Ghana. J Dev Agric Econ 30 (5):161-167

Anaglo JN, Boateng SD, Boateng CA (2014) Gender and access to agricultural resources by smallholder farmers in the upper west region of Ghana. J Educ Pract 5(5). http://www.iiste.org

Anuga SW, Gordon C (2016) Adoption of climate-smart weather practices among smallholder food crop farmers in the Techiman municipal: implication for crop yield. Res J Agric Environ Manage 5(9):279-286

Anuga SW, Gordon C, Boon E, Musah-Issah JS (2019) Determinants of climate smart agriculture (CSA) adoption among smallholder food crop farmers in the Techiman municipality, Ghana. $\mathrm{J}$ Geogr 11(1):124-139. https://doi.org/10.4314/gjg.v11i1.8

Asenso-Okyere K, Mekonnen DA (2012) The importance of ICTs in the provision of information for improving agricultural productivity and rural incomes in Africa. Working Paper 2012- 
015. United Nations Development Programme's Regional Bureau for Africa, Addis Ababa. Available at http://web.undp.org/africa/knowledge/WP-2012-015-okyere-mekonnen-ict-produc tivity.pdf

Asuru S (2017) The new philanthropy and smallholder farmers' livelihoods. A case study of the Alliance for a Green Revolution in Africa (AGRA) in the northern region of Ghana. Doctoral thesis, University of Bradford

Barber J, Mangnus E, Bitzer V (2016) Harnessing ICT for agricultural extension. KIT working paper 4. Amsterdam. Accessed from https:/www.kit.nl/wp-content/uploads/2019/10/KIT_ WP2016-4 Harnessing-ICT-for-agricultural-extension.pdf

Bell M (2015) Information and communication technologies for agricultural extension and advisory services. ICT-powering behavior change for a brighter agricultural future. MEAS Project, Urbana

Bennett WL, Segerberg A (2012) The logic of connective action: digital media and the personalization of contentious politics, information. Commun Soc 15:739-768. https://doi.org/10.1080/ 1369118X.2012.670661

Buytaert W, Zulkafli Z, Grainger S, Acosta L, Alemie TC, Bastiaensen J et al (2014) Citizen science in hydrology and water resources: opportunities for knowledge generation, ecosystem service management, and sustainable development. J Front Earth Sci 2:1-21. https://doi.org/10.3389/ feart.2014.00026

Caine A, Dorward P, Clarkson G, Evans N, Canales C, Stern D (2015) Review of mobile applications that involve the use of weather and climate information: their use and potential for Smallholder Farmers. CCAFS working paper no150. CGIAR Research Program on Climate Change, Agriculture and Food Security (CCAFS), Copenhagen. Available online at: http:// www.ccafs.cgiar.org

Chapman R, Blench R, Kranjac-Berisavljevic G, Zakariah ABT (2003) Rural radio in agricultural extension: the example of vernacular radio programmes on soil and water conservation in Ghana. Network paper no 127. Overseas Development Institute, London

Chaudhury M, Kristjanson P, Kyagazze F, Naab JB, Neelormi S (2012) Participatory gendersensitive approaches for addressing key climate change-related research issues: evidence from Bangladesh, Ghana, and Uganda. Working paper 19. CGIAR Research Program on Climate Change, Agriculture and Food Security (CCAFS), Copenhagen

Chudaska R (2018) Informational governance: exploring how the flow of water-related information affects farming practices and decision-making in Ada east. Master thesis, Wageningen University

Cieslik K, Leeuwis C, Dewulf A, Feindt P, Lie R, Werners S et al (2018) Addressing socio ecological development challenges in the digital age: environmental virtual observatories for connective action. NJAS Wagening J Life Sci 86-87:2-11

Clarksona G, Dorward P, Osbahra H, Torgbor F, Kankam-Boadu I (2019) An investigation of the effects of PICSA on smallholder farmers' decision making and livelihoods when implemented at large scale-the case of northern Ghana. Clim Serv 14:1-14

Dilling L, Lemos MC (2011) Creating usable science: opportunities and constraints for climate knowledge use and their implications for science policy. Glob Environ Chang 21:680-689

Dinku T, Thomson MC, Cousin R, del Corral J, Ceccato P, Hansen J, Connor SJ (2018) Enhancing national climate services (ENACTS) for development in Africa. Clim Dev 10(7):664-672. https://doi.org/10.1080/17565529.2017.1405784

Dougill AJ, Whit S, Stringer LC, Vincent K, Wood BT, Chinseu EL et al (2017) Mainstreaming conservation agriculture in Malawi: knowledge gaps and institutional barriers, 195. https://doi. org/10.1016/j.jenvman.2016.09.076

Drafor I (2016) Access to information for farm-level decision-making. J Agric Food Inf 17(4):230 245. https://doi.org/10.1080/10496505.2016.1213170

Drafor I, Atta-Agyepong K (2005) Local information systems for community development in Ghana. In: Dixon J, Wattenbach H, Bishop-Sambrook C (eds) Improving information flows to the rural community. FAO, Rome, pp 5-19

Dumenu WK, Obeng EA (2016) Climate change and rural communities in Ghana: social vulnerability, impacts, adaptations and policy implications. Environ Sci Policy 55:208-217. https:// doi.org/10.1016/j.envsci.2015.10.010 
Duncombe R (2016) Mobile phones for agricultural and rural development: a literature review and suggestions for future research. Eur J Dev Res 28:213-235. https://doi.org/10.1057/ejdr.2014.60

Eitzingera A, Cocka J, Atzmanstorferc K, Binder CR, Läderacha P, Bonilla-Findjia O, Bartling M, Mwongeraa C, Zuritae L, Jarvisa A (2019) GeoFarmer: a monitoring and feedback system for agricultural development projects. Comput Electron Agric 158:109-121

Etwire PM, Buah S, Ouédraogo M, Zougmoré R, Partey ST, Martey E, Djibril SD, Bayala J (2017) An assessment of mobile phone-based dissemination of weather and market information in the Upper West Region of Ghana. J Agric Food Secur 6:8. https://doi.org/10.1186/s40066-0160088-y

Federspiel S (2013) Climate change adaptation planning, implementation and evaluation: needs, resources and lessons for the 2013 National Climate Assessment. University of Michigan School of Natural Resources and Envirnment, Ann Arbor

Gbetibouo G, Hill C, Abazaami J, Mills A, Snyman D, Huyser O (2017) Impact assessment on climate information services for community-based adaptation to climate change: Ghana country report. CARE international adaptation learning program, Ghana. http://careclimatechange.org/ wp-

Gotamey A, Shankar A, Toomasson T (2018) Rain forecasting service for rural Ghana implementation prototype report. ICT4D: Information and Communication Technology for Development (X_405101), Amsterdam

Graham R, Visman E, Wade S, Amato R, Bain C, Janes T, Leathes B, Lumbroso D, Cornforth R, Boyd E, Parker D (2015) Scoping, options analysis and design of a 'Climate Information and Services Programme’ for Africa (CIASA). Lit Rev. https://doi.org/10.12774/eod_cr.may2015. grahamr

Hansen JW, Vaughan C, Kagabo DM, Dinku T, Carr ER, Körner J, Zougmoré RB (2019) Climate services can support African Farmers' context-specific adaptation needs at scale. Front Sustain Food Syst 3(21). https://doi.org/10.3389/fsufs.2019.00021

Ibrahim N, Teye MK, Alhassan H, Adzawla W, Adjei-Mensah C (2019) Analysis of smallholder farmers' perceptions on climate change, preference and willingness-to-pay for seasonal climate forecasts information in Savelugu Municipality, Ghana. Asian J Environ Ecol 9(1):1-11, Article no.AJEE.47872 ISSN: 2456-690X

IPCC (2014) Climate change 2014: impacts, adaptation, and vulnerability. Part A: global and sectoral aspects. In: Field CB, Barros VR, Dokken DJ, Mach KJ, Mastrandrea MD, Bilir TE, Chatterjee M, Ebi KL, Estrada YO, Genova RC, Girma B, Kissel ES, Levy AN, MacCracken S, Mastrandrea PR, White LL (eds) Contribution of working group II to the fifth assessment report of the Intergovernmental Panel on Climate Change. Cambridge University Press, Cambridge, UK/New York, $1132 \mathrm{pp}$

Jost C, Kyazze F, Naab J, Neelormi S, Kinyangi J, Zougmore R et al (2016) Understanding gender dimensions of agriculture and climate change in smallholder farming communities. J Clim Dev 8:133-144

Kadi M, Njau LN, Mwikya J, Kamga A (2011) The state of climate information services for agriculture and food security in West African Countries. CCAFS working paper no 4. Copenhagen. Available online at: http://www.ccafs.cgiar.org

Karpouzoglou T, Zulkafli Z, Grainger S, Dewulf A, Buytaert W, Hannah DM (2016) Environmental virtual observatories (EVOs): prospects for knowledge co-creation and resilience in the information age. Curr Opin Environ Sustain 18:40-48. https://doi.org/10.1016/j.cosust. 2015.07.015

Kirbyshire A, Wilkinson E (2018) Challenging assumptions: What impact are NGOs having on the wider development of climate services? Research, reports and studies. Overseas Development Institute. https://www.odi.org/sites/odi.org.uk/files/resources-documents/...

Leeuwis C (2004) Communication for rural innovation: rethinking agricultural extension. Blackwell Science, Oxford

Lemos MC, Kirchhoff CJ, Ramprasad V (2012) Narrowing the climate information usability gap. J Clim Change 2(11):789-794 
Materia VC, Giarè F, Klerkx L (2015) Increasing knowledge flows between the agricultural research and advisory system in Italy: combining virtual and non-virtual interaction in communities of practice. J Agric Educ Ext 21:203-218. https://doi.org/10.1080/1389224X.2014. 928226

McNamara P, Dale J, Keane J, Ferguson O (2014) Strengthening pluralistic agricultural extension in Ghana: a MEAS Rapid Scoping Mission, Accra. Modernizing extension and advisory services discussion paper. USAID, Illinois.

McOmber C, Panikowski A, McKune S, Bartels W, Russo S (2013) Investigating climate information services through a gendered lens. CCAFS working paper no 42. CGIAR Research Program on Climate Change, Agriculture and Food Security (CCAFS). Copenhagen. Available online at: http://www.ccafs.cgiar.org

Mills A, Huyser O, van den Pol O, Zoeller K, Snyman D, Tye N, McClure A (2016) UNDP market assessment: revenue generating opportunities through tailored weather information products. UNDP, New York. License: Creative Commons Attribution CC BY 3.0 IGO

Modernizing Extension and Advisory Services (MEAS) (2012) Rapid appraisal of the ICT for agricultural extension landscape in Ghana. Retrieved from the MEAS website: http://www. meas-extension.org

Mohammed HN (2018) Digital tools and smallholder agriculture: the role of ICT-enabled extension services in rural smallholder farming in northern Ghana. Master of Arts in Development Studies, International Institute of Social Studies

Mol APJ (2008) Environmental reform in the information age - the contours of informational governance. Cambridge University Press, Cambridge

Munthali N, Leeuwis C, van Paassen A, Lie R, Asare R, van Lammeren R, Schut M (2018) Innovation intermediation in a digital age: comparing public and private new-ICT platforms for agricultural extension in Ghana. Wagening J Life Sci 86-87:64-76

Naab FZ, Abubakari Z, Ahmed A (2019) The role of climate services in agricultural productivity in Ghana: the perspectives of farmers and institutions. Clim Serv 13:24-32

Nantui F, Nketiah MP, Darko D (2014) Farmers' willingness to pay for weather forecast information in Savelugu-Nanton municipality of the northern region. RJOAS 12(36):34

Nyadzi E (2020) Best of both worlds: co-producing climate services that integrate scientific and indigenous weather and seasonal climate forecast for water management and food production in Ghana. $\mathrm{PhD}$ thesis, Wageningen University

Nyamekye AB (2020) Towards a new generation of climate information systems information systems and actionable knowledge creation for adaptive decision-making in Rice Farming Systems in Ghana. PhD thesis, Wageningen University

Nyantakyi-Frimpong H (2013) Indigenous knowledge and climate adaptation policy in northern Ghana. The Africa portal backgrounder, number 48. Center for International Governance Innovation, Waterloo

Nyantakyi-Frimpong H (2019a) Unmasking difference: intersectionality and smallholder farmers' vulnerability to climate extremes in Northern Ghana. Gender Place Cult. https://doi.org/10. 1080/0966369X.2019.1693344

Nyantakyi-Frimpong H (2019b) Combining feminist political ecology and participatory diagramming to study climate information service delivery and knowledge flows among smallholder farmers in northern Ghana. Appl Geogr 112:102079

Nyarko Y, Hildebrandt N, Romagnoli G, Soldani E (2013) Market information systems for rural farmers evaluation of Esoko MIS - year 1 results. Blog Post, Cent Technol Econ Dev NYU. http://www.nyucted.org/archives/1108

Omoine H, Chen HM, Akhtar I (2013) RainCast: a voice based weather service for Rural Ghana. Accessed from https://w4ra.org/wp-content/uploads/2018/08/Raincast.pdf

Padgham J, Devisscher T, Togtokh C, Mtilatila L, Kaimila E, Mansingh I, Agyemang-Yeboah F, Obeng FK (2013) Building shared understanding and capacity for action: insights on climate risk communication from India, Ghana, Malawi, and Mongolia. Int J Commun 7:970-983. 1932-8036/20130005. Available at http://ijoc.org 
Partey ST, Nikoi GK, Ouédraogo M, Zougmoré RB (2019) Scaling up climate information services through public-private partnership business models: an example from northern Ghana. CCAFS Info note. https://hdl.handle.net/10568/101133

Partey ST, Dakorah AD, Zougmoré RB, Ouédraogo M, Nyasimi M, Nikoi GK, Huyer S (2020) Gender and climate risk management: evidence of climate information use in Ghana. Clim Chang. https://doi.org/10.1007/s10584-018-2239-6

Perkins K, Huggins-Rao S, Hansen J, van Mossel J, Weighton L, Lynagh S (2015) Interactive radio's promising role in climate information services: Farm Radio International concept paper. CCAFS working paper no 156. CGIAR Research Program on Climate Change, Agriculture and Food Security (CCAFS), Copenhagen. Available online at: http://www.ccafs.cgiar.org

Quaye W, Asafu-Adjaye NY, Yeboah A, Osei C, Agbedanu EE (2017) Appraisal of the agro-tech smart extension model in Ghana, payment options and challenges in ICT-enabled extension services delivery. Int J Agric Educ Ext 3(2):72-84

Sam J, Dzandu L (2016) The use of radio to disseminate agricultural information to farmers: the Ghana agricultural information network system (GAINS) experience. Agric Inf Worldw 11:1723

Sarku R, Dewulf A, Slobbe VE, Termeer K, Kranjac-Berisavljevic G (2020) Adaptive decisionmaking under conditions of uncertainty: the case of farming in the Volta delta, Ghana. J Integr Environ Sci 17(1):1-33. https://doi.org/10.1080/1943815X.2020.1729207

Sarku R, Gbangou T, Dewulf A, Slobbe VE (forthcoming) Beyond 'experts knowledge': locals and experts in a joint production of weather App and weather information for farming in the Volta Delta, Ghana. In: Handbook of climate change management: research, leadership, transformation. Springer, New Delhi

Singh C, Urquhart P, Kituyi E (2016) From pilots to systems: barriers and enablers to scaling up the use of climate information services in smallholder farming communities. CARIAA working paper no 3. International Development Research Centre/UK Aid, Ottawa/London. Available online at: http://www.idrc.ca/cariaa

Singh C, Daron J, Bazaz A, Ziervogel G, Spear D, Krishnaswamy J, Zaroug M, Kituyi E (2018) The utility of weather and climate information for adaptation decision-making: current uses and future prospects in Africa and India. Clim Dev 10(5):389-405. https://doi.org/10.1080/ 17565529.2017 .1318744

Slavova M, Karanasios S (2018) When institutional logics meet information and communication technologies: examining hybrid information practices in Ghana's agriculture. J Assoc Inf Syst 19(9):775-812. https://doi.org/10.17705/1jais.00509

Soma K, MacDonald BH, Termeer CJAM, Opdam P (2016) Introduction article: informational governance and environmental sustainability. J Curr Opin Environ Sustain 18:131-139. https:// doi.org/10.1016/j.cosust.2015.09.005

Stigter K, Winarto YT, Ofori E, Zuma-Netshiukhwi G, Nanja D, Walker S (2013) Extension agrometeorology as the answer to stakeholder realities: response farming and the consequences of climate change. J Atmos 4:237-253. https://doi.org/10.3390/atmos4030237

Suchiradipta B, Saravanan R (2016) Social media: shaping the future of agricultural extension and advisory services. GFRAS interest group on ICT4RAS discussion paper. GFRAS, Lindau. Accessed from Social media: Shaping the future of agricultural ... - GFRAS. http://www.gfras.org/knowledge/gfras-publications

Sulaiman RV, Hall A, Kalaivani NJ, Dorai K, Reddy TSV (2012) Necessary, but not sufficient: critiquing the role of information and communication technology in putting knowledge into use. J Agric Educ Ext 18:331-346. https://doi.org/10.1080/1389224X.2012.691782

Tall A, Hansen J, Jay A, Campbell B, Kinyangi J, Aggarwal PK, Zougmoré R (2014) Scaling up climate services for farmers: mission possible. Learning from good practice in Africa and South Asia. CCAFS report no 13. CGIAR Research Program on Climate Change, Agriculture and Food Security (CCAFS), Copenhagen

Usher J, Phiri C, Linacre N, O’Sullivan R, Qadir U (2018) Climate information Services market assessment and business model review. USAID-supported Assessing Sustainability and Effectiveness of Climate Information Services in Africa Project, Washington, DC 
Vaughan C, Dessai S (2014) Climate services for society: origins, institutional arrangements, and design elements for an evaluation framework. J Clim Change 5(5):587-603. https://doi.org/10. $1002 /$ wcc. 290

Vogel C, Steynor A, Manyuchi A (2019) Climate services in Africa: re-imagining an inclusive, robust and sustainable. Clim Serv 15:100107

World Meteorological Organization (2015) Valuing weather and climate: economic assessment of meteorological and hydrological services. WMO-No 1153. WMO, Geneva

Zougmoré RB, Partey ST, Ouédraogo M, Torquebiau E, Campbell BM (2018) Facing climate variability in sub-Saharan Africa: analysis of climate-smart agriculture opportunities to manage climate-related risks. Cahiers Agric 27(3):1-9

\section{Websites}

CTA, Ghana. https://www.cta.int/en-GB/search?location $=2300660$

ESOKO (2020). https://esoko.com/blog/

African Cashew initiative (2020). https://www.comcashew.org/

FARM Radio International (2020). https://farmradio.org/about/

Ghana Meteorological Agency (2020). https://www.google.nl/search?source=hp\&ei=5XZqXvf3 JIHWkwWUya34Dg\&q=ghana + meteorological+agency\&oq=Ghana + meteoro\&gs_l=psy-

Rainsat Ghana. http://www.rainsat.net/index.html?country=Ghana

ACDI/VOCA. https://www.acdivoca.org/projects/agricultural-development-and-value-chainenhancement-ii-advance-ii-project/

Farmerline. https://farmerline.co/

Cocoalink. https://cocobod.gh/coco_link.php

Smartex. https://www.idrc.ca/en/research-in-action/improving-farming-practices-ghana-radio-andcell-phones

PISCA. https://research.reading.ac.uk/picsa/

Open Access This chapter is licensed under the terms of the Creative Commons Attribution 4.0 International License (http://creativecommons.org/licenses/by/4.0/), which permits use, sharing, adaptation, distribution and reproduction in any medium or format, as long as you give appropriate credit to the original author(s) and the source, provide a link to the Creative Commons license and indicate if changes were made.

The images or other third party material in this chapter are included in the chapter's Creative Commons license, unless indicated otherwise in a credit line to the material. If material is not included in the chapter's Creative Commons license and your intended use is not permitted by statutory regulation or exceeds the permitted use, you will need to obtain permission directly from the copyright holder.

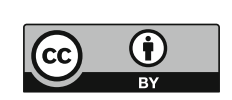

